\title{
MUFRADAT LEARNING STRATEGY WITH MULTIPLE INTELLIGENCES-BASED CLASSROOM MANAGEMENT: CASE STUDY AT SD AL-KAUTSAR MALANG
}

\author{
Rizka Widayanti \\ e-mail: uni_qoen@yahoo.com \\ Sekolah Tinggi Agama Islam Darul Qur'an Payakumbuh \\ Dian Febrianingsih \\ e-mail: dianfebrianingsih@gmail.com \\ Sekolah Tinggi Ilmu Tarbiyah Islamiyah Karya Pembangunan Paron Ngawi
}

\begin{abstract}
This paper aims to describe the concept of mufradat learning strategies at SD AlKautsar Malang which are packaged using multiple intelligences-based classroom management and to understand the factors that influence the success of the learning strategy in each class. The author used descriptive qualitative research methods. The results showed that SD Al-Kautsar has organized a learning program well which is marked by the application of a mufradat learning strategy based on multiple intelligences class management by producing various mufradat learning strategies, as well as the factors that influence the success of mufradat learning at SD Al-Kautsar including strong funding, reliable buman resource management, as well as facilities and infrastructure factors.
\end{abstract}

Key Words: Mufradat, learning strategy, multiple intelligences, classroom management.

\begin{abstract}
Abstrak: Penelitian ini bertujuan untuk mendeskripsikan konsep strategi pembelajaran mufradat yang diterapkan di SD Al-Kautsar Malang yang dikemas dengan menggunakan manajemen kelas berbasis kecerdasan majemuk dan untuk memahami faktor-faktor yang mempengaruhi keberhasilan strategi pembelajaran di setiap kelas. Peneliti menggunakan metode penelitian kualitatif deskriptif. Hasil penelitian menunjukkan bahwa SD Al-Kautsar telah menyelenggarakan program pembelajaran dengan baik yang ditandai dengan penerapan strategi pembelajaran mufradat berbasis manajemen kelas kecerdasan majemuk dengan menghasilkan berbagai strategi pembelajaran mufradat, serta faktor-faktor yang mempengaruhi keberhasilan pembelajaran mufradat di SD Al-Kautsar adalah pendanaan yang kuat, manajemen sumber daya manusia yang handal, juga faktor sarana prasarana. Kata kunci: Mufradat, strategi pembelajaran, kecerdasan majemuk, manajemen kelas.
\end{abstract}

\section{INTRODUCTION}

Elementary school is an important level of education in instilling foreign language skills. This is because elementary school level is a fundamental initial period throughout the range of growth and development of human life (Ruhaina \& Yusuf, 2019). Language acquisition obtained from an early age produces a more optimal foreign language learning output. The internalization of some basic skills in the learning process in the global era is very important, given the very complex global demands regarding increasingly fierce world competition.

Education and learning cannot be separated, even the success of education can be said to be very dependent on the effectiveness of learning. This is because the learning process is the spearhead and core of educational activities that will 
affect the achievement of educational goals (Amstrong, 2003).

In fact, learning is a process in an activity that can show levels in learning. Learning can also be an activity to improve the way of thinking in understanding something. Likewise, learning is defined as an activities process that aims to create new perspectives. Learning can be a foundation to know or know something (Yamin, 2015).

If in learning to create new perspectives, then teaching is to create an environment that can lead to the learning process. This environmental system consists of components that influence each other, namely the learning objectives to be achieved, the material being taught, teachers and students who must play a role and be in certain social relationships, the types of activities carried out, and the available teaching and learning facilities and infrastructure (Hasibuan \& Mujiono, 1988).

These components include the material being taught, and it includes vocabulary material (Atabik, 1999) In understanding mufradat as a word, Yaqin expresses that the word is the smallest form unit that stands alone and has meaning (Atabik, 1999).

To master Arabic language skills, vocabulary learning (mufradat) is a basic requirement and requirement for learning it. What is meant by mufradat learning is that students can master vocabulary if students can translate vocabulary forms and can use them incorrect sentences so that in addition to memorizing, students also know how to use them when communicating. So, students who understand vocabulary can use it in the form of speech and writing. (Atabik, 1999)

Based on the 2013 curriculum, the direction of learning Arabic in Madrasah is as follows (Ainin, 2020):

1. Cultivating and developing religious attitudes or religious attitudes of students in the context of learning Arabic. This attitude is reflected in the habituation of prayer before studying, after studying, and the use of religious greetings.

2. Cultivating social attitudes in the form of honesty, mutual respect, courtesy, cooperation, care, environmentally friendly, and other social activities.

3. Cultivating and developing educational attitudes lies in students who are reflected in a disciplined attitude, enthusiastic about learning, responsive, proactive in the learning process.

4. Learning Arabic language elements should be used as basic knowledge to achieve language skills which consist of four language skills (listening, speaking, reading, and writing)

5. Vocabulary learning should be avoided by direct translation. But using a method or media that shows the opposite, equivalent, or movement.

6. In learning sentence structure, avoid theoretical-analytical learning that hinders students from mastering language skills.

7. Arabic teachers develop a language acquisition learning process so that learning activities emphasize communication optimally.

8. The evaluation system emphasizes an authentic assessment system that explicitly emphasizes the three domains of cognitive, affective, and psychomotor domains.

Almost 80 years after the first intelligence tests were developed, a Harvard psychologist named Howard Gardner challenged this commonly held belief. Saying that our culture had defined intelligence too narrowly, he proposed in the book Frames of Mind, the existence of at least nine basic intelligences. Gardner provided a means of mapping the board range of abilities that humans 
posess by grouping their capabilities into the following eight comprehensive categories:

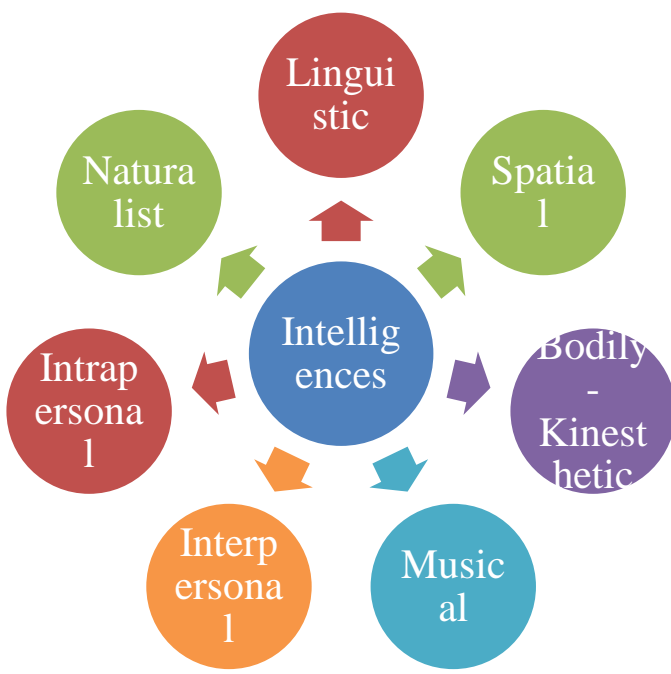

\section{Multiple Intelligences Chart}

Instead, Gardner suggested that intelligence has more to do with the capacity for (1) naturalistic setting. Gardner suggests that intelligences are galvanized by participation in some kind of culturally valued activity and that the individual's growth in such an activity follows a developmental pattern. Each intelligence-based activity has its own developmental trajectory; that is, each activity has its own time of arising in early childhood, its own time of peaking duringone's lifetime, and its own pattern of either rapidly or gradually declining as one gets older. (Armstrong, 2009).

Various problems in learning Arabic, namely when the teacher uses a monotonous learning model, such as lecturing techniques so that students feel boredom in carrying out learning (Nandang, 2012). Based on the facts above, there is a need for innovations to optimize the achievement of mufradat learning objectives at the elementary school level.

One form of innovation in learning is classroom management based on multiple intelligences, in which the teacher's teaching style is adjusted to the student's learning style (Arifka, 2019), so that students feel the learning process has an urgent meaning because classroom management is an urgent challenge for teachers (Suleyman, 2015). As the use of Multiple Intelligence-based learning means using an interdisciplinary approach in developing learning material content, using multi-learning models, and using authentic assessment in the evaluation of learning.

All are intended to accommodate the diversity of intelligence possessed by students (Titin, 2015). Various studies with the theme of Multiple Intelligences have been carried out. One study found a global strategy that could be used by all students in the class concerned. There is an interview review sheet in the form of students' impressions during the learning process with the concept of Multiple Intelligences, resulting in several media from the learning outcomes including crossword puzzle media made by students, the relevant vocabulary song and instruments, a collection of pictures posted on the classroom wall from the results of group work demonstrated in front of the class (Yuli, 2018).

Each student is unique (Amitha, 2017). The existence of differences in intelligence that is more dominant should be able to produce and target teachers to use structured mufradat learning strategies and produce balanced and relevant student output in today's times.

As previous research has revealed about the multiple intelligences classbased language learning process with the findings that the language environment is very supportive of students' skills based on their intelligence. The study addressed to explore classroom management and Arabic Learning process based on multiple intelligences theory implemented by the teacher. The students were classified based on their intelligences with interview and appropriate test of multiple intelligences done by MIR team. 
Therefore, Arabic teacher implemented a suitable method in the Arabic learning process for each class based on their needs. Yet, the teacher faced an obstacle when teaching the students with logicalmathematical and interpersonal intelligences. Another data indicated that classroom was not only the class for learning, sometimes the teacher challenged the students to study outdoor, school environment. The school environment and facilities contributed to support learning process and give the students more space to be creative and aware with what they found in the school environment (Mahmudi, et al., 2019). In addition, research on learning innovations using a system of multiple intelligences has been applied by classifying students based on their dominant intelligence which is more effective (Truong, 2016). There is a relationship between student personality and the learning model used in multiple intelligences class management (Baber, 2015). Classroom management based on multiple intelligences also pays attention to students' interest in the learning process (Milad, 2019). In addition, a review of the relationship between multiple intelligence-based classroom management is able to produce positive relationships with teachers and students in the context of learning interactions (Amitha \& Ahm, 2017).

Likewise, the results of other studies have found strategies that can be used globally by all students in the class concerned. There is an interview review sheet in the form of students' impressions during the learning process with the concept of Multiple Intelligences, resulting in several media from the learning outcomes including crossword puzzle media made by students, the relevant vocabulary song and instruments, a collection of pictures pasted on the classroom wall from the results of group work demonstrating in front of the class (Yuli, 2018).

Research on Multiple Intelligencesbased learning is a form of learning innovation that can be an option for Islamic Religious Education teachers in Indonesia. Applying Multiple Intelligences-based learning means using an interdisciplinary approach in developing learning material content, using multimodel learning and using authentic assessment in the evaluation of learning. This is intended to accommodate the diversity of intelligence possessed by students (Titin, 2015).

In addition, a review of the relationship between multiple intelligence-based classroom management is able to produce a positive relationship in improving students' language skills. The study proved that learning Arabic with Howard Gardner's Multiple intelligences theory approach has a positive effect and very effective in improving students' language skills. Islamic boarding school with integrated, integrative and comprehensive education system has applied this theory in the process of learning Arabic, both in class and in the Islamic boarding school environment with the support of kyai, teachers, and representative facilities. Therefore, it is only natural that nine intelligences (Howard Garder's Multiple Intelligences Theory) have been applied. The nine intelligences are linguistic intelligence (language), visual-spatial intelligence, musical intelligence, interpersonal intelligence (social), mathematical logical intelligence, kinesthetic intelligence, intrapersonal intelligence, natural st intelligence, and spiritual intelligence.(Ubaid Ridho, 2019). It also has a positive effect on improving students' language skills by applying multiple intelligences class management. There is a significantly effect of MIstrategy on the development of students MI and SPS. The implementation of MI- 
strategy in this study improves MI and SPS of students. Six stages of the MI based learning process, which consist of (1) self-reflection (2) introduction of the concept, (3) formulation of the question, (4) concept exploration, (5) talent show, and (6) formulation of conclusions, proved to be effective in improving five types of intelligences, namely interpersonal, intrapersonal, visual-spatial, kinesthetic and musical intelligence. The simple learning strategy steps make this strategy easy to use in the classroom, without having to create a special program as it was applied to the previous researches (Atiek Winarti et al, 2019).

For this reason, there is a need for fundamental studies related to further research to analyze vocabulary learning strategies using a Multiple Intelligencebased classroom management system at SD Plus Al-Kautsar.

\section{RESEARCH METHODS}

In this study, the authors used descriptive qualitative research methods, as an attempt to describe the phenomena in the use of multiple intelligences classbased mufradat learning strategies. This alternative learning strategy model was chosen as an approach to analyze the learning strategy development process carried out at SD Al-Kautsar, as well as the determinants that influence the success of the multiple intelligence-based mufradat learning strategies.

Data were collected from observations, interviews, and field studies. Through observations, interviews, and field studies, observations can be made on the mufradat learning process that runs at SD Al-Kautsar, as well as knowing the factors that affect the success of developing learning strategies as a curriculum model based on multiple intelligences. Various forms of secondary data are used to supplement primary data, such as written sources and relevant documents. The informants of in this study were teachers, students, deputy head of the curriculum. The collected data is then analyzed using data analysis techniques similar to those of Miles and Hubbermans (Miles \& Hubbermans, 2009), which collect data, describe, then reduce and verify.

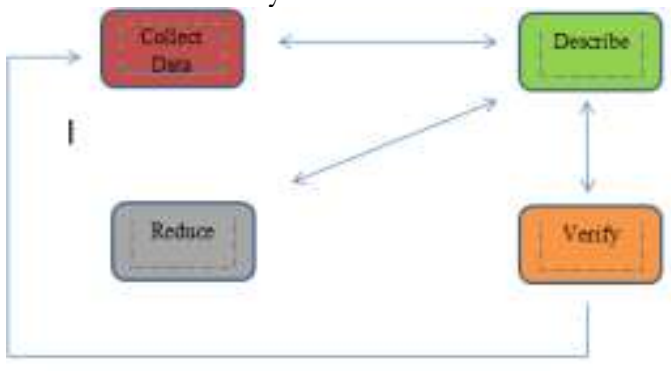

At the data collection stage, the researcher observed the mufradat learning process carried out. After the data is collected, the researcher then reduces the data by selecting and sorting the data that supports the research. Furthermore, verification at this stage the researcher determines the core data as important and supporting data, and removes unnecessary data.

\section{RESEARCH RESULTS AND DISCUSSION}

The use of the curriculum at SD Al-Kautsar is integrated in an integrated manner, both from the International, National, school specificities, and wellstructured local content. Since the 20132014 school year, SD Al-Kautsar has implemented the 2013 curriculum in stages. At this time, SD Al-Kautsar uses the 2013 curriculum as a whole. The content of the curriculum developed following Permendikbud No. 57 of 2014 concerning the SD / MI Curriculum. Overall, the curriculum at SD Al-Kautsar is integrated with local content and school-specific content, including character development.

As Permendikbud (Regulation of the Minister of Education and Culture) No.57 of 2014 concerning the 2013 primary school curriculum is implemented in grades 1-6, the 
curriculum at SD Al-Kautsar Elementary Scool consists of the following concepts.

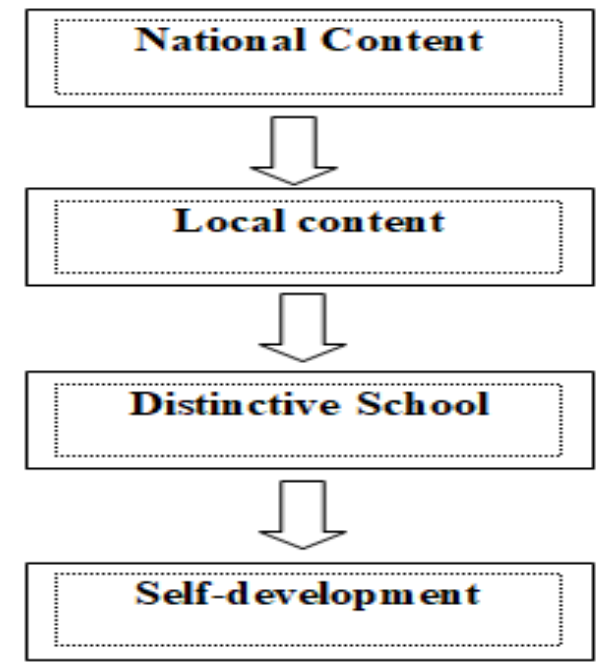

The development of the Arabic language curriculum is included in the school's distinctive curriculum which has an allocation of 2 hours of learning time. Learning Arabic has started in grade 1 to grade 6. Besides, additional foreign language day activities (Arabic and English) will support the success of learning in class.

The Arabic curriculum developed by SD Al-Kautsar is packaged with class management based on multiple intelligences. Students learn according to their intelligence. Each class has its uniqueness in learning Arabic which has an impact on the different teaching strategies used by Arabic teachers. SD AlKautsar has four study groups at each level. Classroom management based on multiple intelligence is applied to start from grade 3 to grade 5 . For grades 1 and schools still observe the tendencies that students have, while grade 6 is focused on working on questions as an effort to prepare for the National Examination.

Grouping students in the class for grade 1 based on the mapping of reading, writing, arithmetic ability, class 2 continues the grouping of class 1 to strengthen psychological aspects. While classes 3-5 are based on the results of multiple intelligence research. It is known that the class division consists of 20-25 students per class and is divided proportionally between boys and girls. Each class that adopts multiple intelligence class management, then two intelligence tendencies are accommodated. The class division can be seen in the following figure.

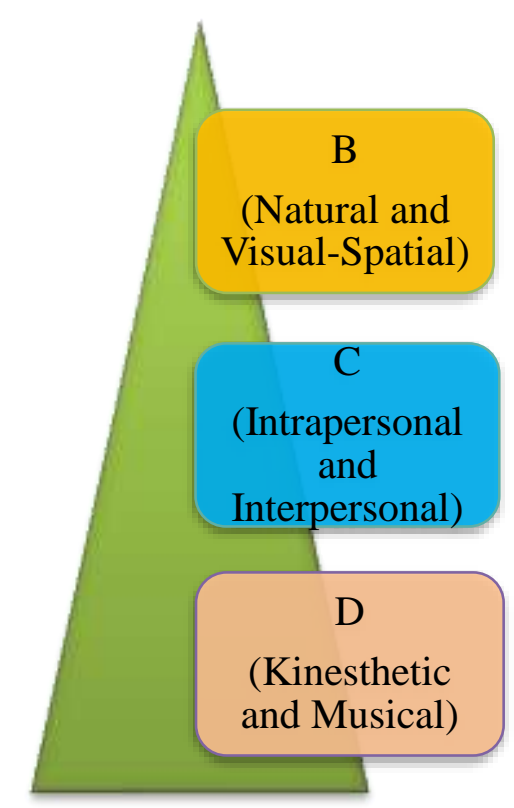

\section{Class division based on student intelligence}

Meanwhile, class 6 uses a tracking system (order of obtaining try out values). The number of study groups starting from grade 1 - 6 in 25 study groups with a maximum student capacity of 27 students.

Al-Kautsar Elementary School adopts a learning system that is packaged with multiple intelligences class management, which is one intelligences in one class. But at the Al-Kautsar the intelligence that has the same tendency will be put into one class. This will have an impact on the use of different teacher learning strategies. Mufradat learning strategies in particular have significant differences in the process of core activities so that the supporting media used are also different. 
The following is an explanation of the different mufradat learning strategies for each class.
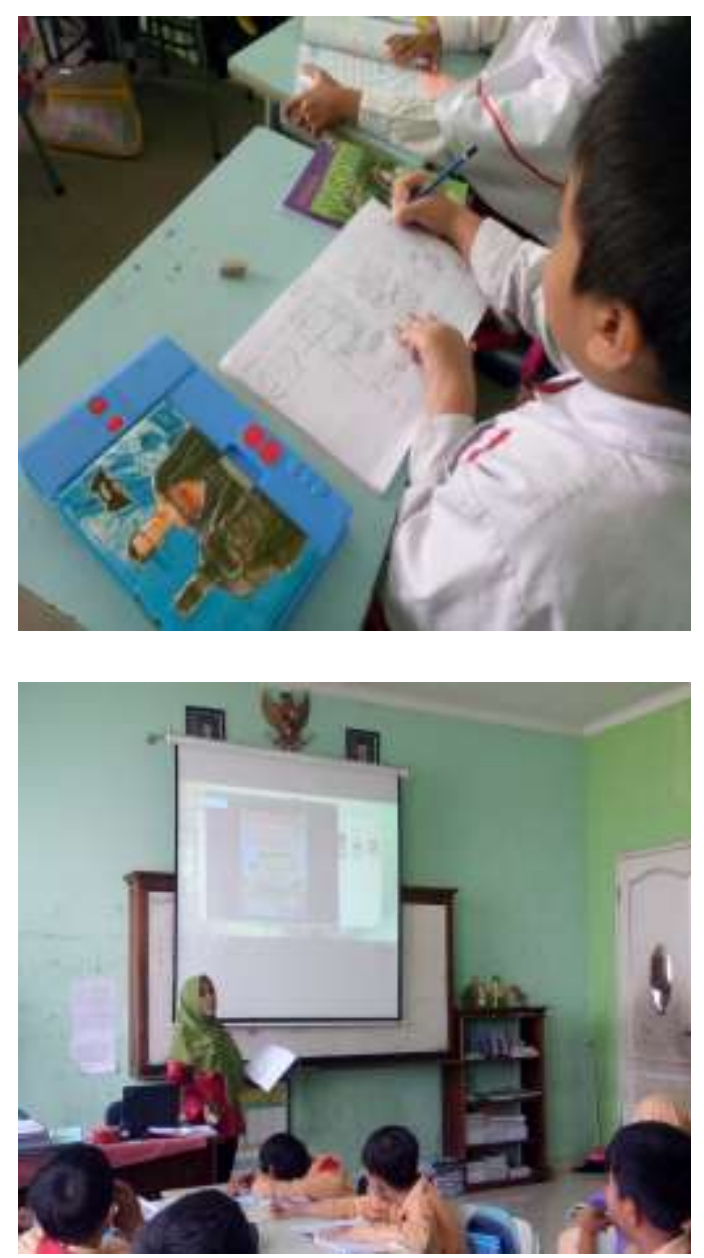

Learning Activities for Children with Visual-Spatial and Natural Intelligence

Class B, which is a student of natural and visual-spatial intelligence, adopts learning activities such as the following: a) The teacher manages the class to do the neglect zone as a first step in starting learning, such as reflecting on previous learning by asking for previous material by guessing words and continuing the words about the material being studied. b) The teacher prepares the learning media that will be used in the form of a video containing the material to be studied at that time. c) The teacher uses a learning strategy by inviting students to watch videos that contain mufradat on the theme being studied and inviting students to make a mind mapping of the vocabulary being studied. e) The teacher prepares a quiz to see the development of students' mufradat mastery by the material being studied in the form of cognitive questions, f) The teacher instructs students to work on quizzes that must be done.

The teacher's assessment takes the form of project assignments, such as writing mufradat, and filling out quizzes that are done. Through some of the above activities, the teacher can assess students from the affective, cognitive, and psychomotor aspects in a balanced way. Through the movement of students in learning, filling out quizzes, and responding to activities given by the teacher, at that time students have been observed to be assessed.

After the assessment has been carried out, the teacher reinforces the material where there are still errors through the distribution of material thoroughly. This is so that students can correct mufradat speech and writing that are still wrong so that students can find out what parts of the error need to be corrected in the corrected theme.

From the strategy used by the teacher in learning mufradat in this class, it is hoped that students will be able to explain the meaning of the mufradat in the story in the form of mind mapping. This is so that students can express the mufradat that students hear and see according to students' thoughts and understanding. with the theory of learning strategies that exist in learning based on multiple intelligences class management, namely the strategy of watching videos and making mind mapping which is one of the learning strategies used for natural and visualspatial intelligence students.

Meanwhile, class $C$ where students are adjusted to intrapersonal and interpersonal intelligence. In the first 
step, the teacher invites students to make groups. In each group, there is a card about the mufradat that will be studied. After that, the teacher explains the mufradat using a card. Then the students were given assignments in groups to arrange the Arabic cards in sequence.

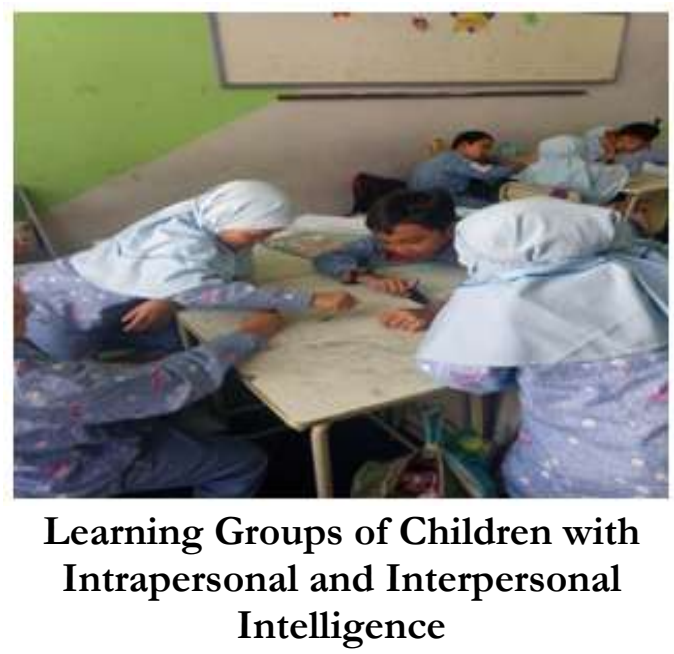

Class D consists of musical and kinesthetic students. The teacher uses a different learning process from classes B and $\mathrm{C}$. In this class, the teacher starts with apperception which aims to repeat the material at the previous meeting, then students are introduced to the new vocabulary using music media. Then the teacher invites students to groups with the aim of each group to compose a song for mufradat. Then, the teacher gives assignments in groups to communicate their work in the form of chants. The learning process using songs can increase student creativity and innovation in arranging sentences according to the theme being studied.

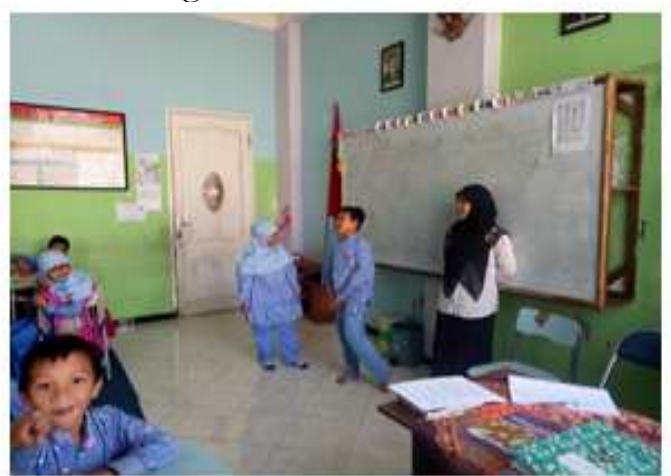

\section{Musical and Kinesthetic Intelligence Student Activities}

It can be seen from the several mufradat learning strategies that have been carried out, there are several strategies and media used by teachers to be an important concern when teachers use multiple intelligence-based classes, namely as follows:

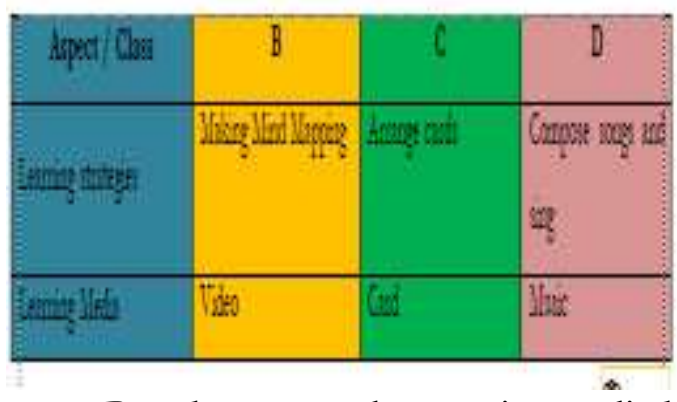

Based on several strategies applied, the teacher needs to understand the needs and correct learning objectives. It aims to measure student competence both in terms of cognitive, affective and psychomotor. With that, the strategy is useful on an ongoing basis to find out students' understanding in learning Arabic. This is consistent with the statement that strategy is not only seen in learning; but the learning process has been carried out starting from the initial learning process itself. So that the assessment given by the teacher is truly authentic and valid.

In general, the implementation of the mufradat learning strategy at SD Plus Al-Kautsar can be described as follows. First, from natural and visual-spatial intelligence classes. These strategies and media are used so that children with natural and visual-spatial intelligence can be more comfortable learning. Second, from intrapersonal and interpersonal intelligence classes. These strategies and media are used so that children with intrapersonal and interpersonal intelligence can learn more. Third, from musical and kinesthetic classes. These strategies and media are used so that children with musical and kinesthetic 
intelligence are more stimulated in their learning because children with this intelligence are identical by always moving and wanting to sing.

In implementing the learning strategies and media used, the Arabic teacher applies the learning process described previously. This gives students the opportunity to process well in learning.

Factors that influence the success of mufradat learning Strong Funding

School funding comes from students who are managed by the foundation, the SPP increase will increase once in 6 years, there is no re-registration fee, but complete funds and annual activities for the benefit of the students themselves. Good financial management will produce good management output. This greatly supports the provision of facilities and infrastructure for students in learning. Such as providing a language environment, a language laboratory that allows for optimal student achievement.

\section{Reliable Human Resource Management Factors}

As the most important school resource, the workforce at SD Al-Kautsar is divided into educators and education staff who provide non-academic services in the administration of both education and non-education with teaching certificates. Meanwhile, for education personnel, at least SMA or the equivalent.

As well as all Human Resources assigned and given workloads are following their potential and competencies. Apart from the main task, there are additional tasks according to their competence. The number of educators and education staff is 98 people, with details of 53 teaching staff, 25 education staff, and 10 Quran reading teachers, and 10 drivers.

Facility and Infrastructure Factor
School facilities are one of the determinants and drivers of student success. Several adequate facilities of the international standard were also developed at Al-Kautsar Elementary School. Classrooms are designed for 2025 students and are equipped with excellent quality facilities and learning media. The existence of a learning resource center that functions as a support for student learning resources, such as providing media, learning tools, and developing learning tools. This facility consists of a library, an art room, a Mathematics and Natural Sciences laboratory, a multimedia room, a music room, an agricultural area, a non-waste tofu production room, a Pull-Out room, and a Green House.

In addition to the means to improve the cognitive and psychomotor domains, there is a need to increase the effectiveness of students in the spiritual realm of Al-Kautsar Elementary School, namely the musala and the Multipurpose Room which are used as places for congregational prayer. Besides, sports facilities in the form of fields and facilities.

\section{CONCLUSION}

The mufradat learning strategy developed by teachers at SD Al-Kautsar has been categorized as a Mufradat learning strategy based on multiple intelligences class management. This is related to the application of SD AlKautsar in the learning process using class management based on multiple intelligences, wherewith multiple intelligences class management the teacher follows student learning styles according to their respective intelligence which has been grouped into classes. The mufradat learning strategy used by the teacher has a good impact on students, they are very enthusiastic in learning and enthusiastic in doing quizzes because the strategy used by the teacher in learning mufradat is following the learning strategy 
in multiple intelligences class management. And with this learning strategy, it is necessary to have factors that influence the success of mufradat learning, including strong funding, environment, reliable human resource management, and facilities and infrastructure factors.

\section{REFERENCES}

Ainin, M. 2020. Pengembangan Kurikulum dalam Pembelajaran Bahasa Arab, 1st edn Malang: Lisan Arabi.

Ali, A. \& Muhdlor, A. Z. 1999. Kamus AlTshry. Yogyakarta: Multi Karya Grafika.

Amitha, V. \& Vijayalaxmi, Ahm. 2017. 'Multiple Intelligence Approach in the School Curriculum: A Review Article', 3.3.

Armstrong, T. 2003. Sekolah Para Juara: Menerapkan Multiple Intelligences di Dunia Pendidikan. Bandung: Kaifa. 2009. Multiple Intelligences in the Classroom. Virgina USA: ASCD.

Baber, W. W. 2015. Cognitive Change among Foreign Managers in Japan's IT Sector. The LAFOR Academic Review, 1(1), 39-47.

Çelik, S. 2015. 'Managing the C Lasses by Using Multiple I Intelligence Instruction', 4.1.

Hasibuan, J. J. \& Moedjiono. 1988. Proses Belajar Mengajar. Bandung: CV Remaja Karya.

Hidayat, N. S. 2012. Problematika Pembelajaran Bahasa Arab. Jurnal Pemikiran Islam, 37 (1). 82-89.

Mahmudi, A., Febriani, S. R., Hasanah, M., Arifa, Z. 2019. Classroom Management and Arabic Learning Process Based on Multiple Intellegences in Elementary School. Arabiyât: Jurnal Pendidikan Bahasa Arab dan Kebahasaaraban, 6(2), 222237.
Milad, M. 2019. Incorporating Brain Colour into the Multiple Intelligences to Create a Blended Learning Context: Homogeneous and Heterogeneous Groups. LAFOR Journal of Language Learning, 4(1), 41-55. https://doi.org/10.22492/ijll.4.1.0 3

Nurhidayati, T. $2015 . \quad$ Inovasi Pembelajaran PAI Berbasis Multple Intelligences. Jurnal Pendidikan Agama Islam, 3 (1).

Ridho, U. 2019. Languange Environment Based on Multiple Intelligences at Islamic Boarding School. Arabiyat: Jurnal Pendidikan Bahasa Arab dan Kebahasaaraban, 6(1). 108-130.

Ruhaina, N. I., Samsudi, \& Yusuf, A. 2019. 'The Management of CharacterBased Holistic Education Program in Early Childhood Education (PAUD) Anak Cerdas Ungaran', 8.51.

Truong, H. M. 2016. Integrating learning styles and adaptive e-learning system: Current developments, problems and opportunities. Computers in Human Behavior, 55, 1185-1193.

https://doi.org/10.1016/j.chb.201 5.02 .014

Winarti, A., Yuanita, L. \& Nur, M. 2019. The Effectiveness of Multiple Intelligences Based Teaching Strategy In Enhancing The Multiple Intelligences And Science Process Skills Of Junior High School Students. Journal of Technology and Science Education JOTSE, 9(2).

Wusthol, Y. M. 2018. Strategi Pembelajaran Kosakata Bahasa Arab Berbasis Kecerdasan Majemuk (Multiple Intelligences), Lisanuna, 8(2). 207-222. 
Yamin, M. 2015.Teori dan Metode Pembelajaran. Malang: Madani.

Zubad, M. N. Y. 2011. Babasa Indonesia Keilmuan. Malang: UIN Maliki Press. 